\title{
Effect of Solid-State Fermentation on Main Nutritional Components, Some Minerals, Condensed Tannin and Phenolic Compounds of Olive Leaves
}

\author{
Aydın Altop* \\ *Department of Animal Science, Faculty of Agriculture, Ondokuz Mayis University, 55200 Samsun, Turkey
} Corresponding Author: Aydin Altop, aaltop@ omu.edu.tr, https://orcid.org/0000-0002-3966-300X

\begin{tabular}{l|l}
\hline \multicolumn{1}{c|}{ A R T I C L E I N F O } & A B S T R A C T \\
\hline $\begin{array}{l}\text { Research Article } \\
\text { Received : 20/09/2018 } \\
\text { Accepted : 16/11/2018 }\end{array}$ & $\begin{array}{l}\text { This study was carried out to investigate the effects of solid-state fermentation (SSF) on main } \\
\text { nutritional components, some minerals, condensed tannin and phenolic compounds of olive } \\
\text { leaves. Two groups were formed as a fermented (FOL, Aspergillus niger ATCC 52172) and non- } \\
\text { fermented olive leaves (OL). Suitable environmental conditions (humidity, temperature and pH) } \\
\text { before SSF were established and fermentation lasted on day 8. After fermentation, while the crude } \\
\text { fiber, neutral detergent fibre (NDF) and acid detergent fibre (ADF) content of FOL compared to } \\
\text { OL were decreased, its the crude protein, ether extract, ash and condensed tannin contents were } \\
\text { increased. Some macro minerals (Ca, N, K, P, Mg) and micro minerals components (Fe, Mn, Zn, } \\
\text { Cu, B) of FOL and OL were varied. Although oleuropein content of FOL was decreased, it's } \\
\text { catechin and hydroxytyrosol contents were increased by SSF. These results showed that A. niger } \\
\text { ATCC 52172 strain could be suitable inoculant to improve the nutritional content of olive leaves. }\end{array}$ \\
$\begin{array}{l}\text { Keywords: } \\
\text { Aspergillus niger } \\
\text { Solid-state fermentation } \\
\text { Olea europea } \\
\text { Olive leaf } \\
\text { Herb }\end{array}$ & \\
\hline
\end{tabular}

Türk Tarım - Gıda Bilim ve Teknoloji Dergisi 7(1): 115-119, 2019

\section{Katı Kültür Fermantasyonun Zeytin Yaprağı Temel Besin Madde, Bazı Mineral Madde, Kondanse Tanen ve Fenolik Bileșenlerine Etkisi}

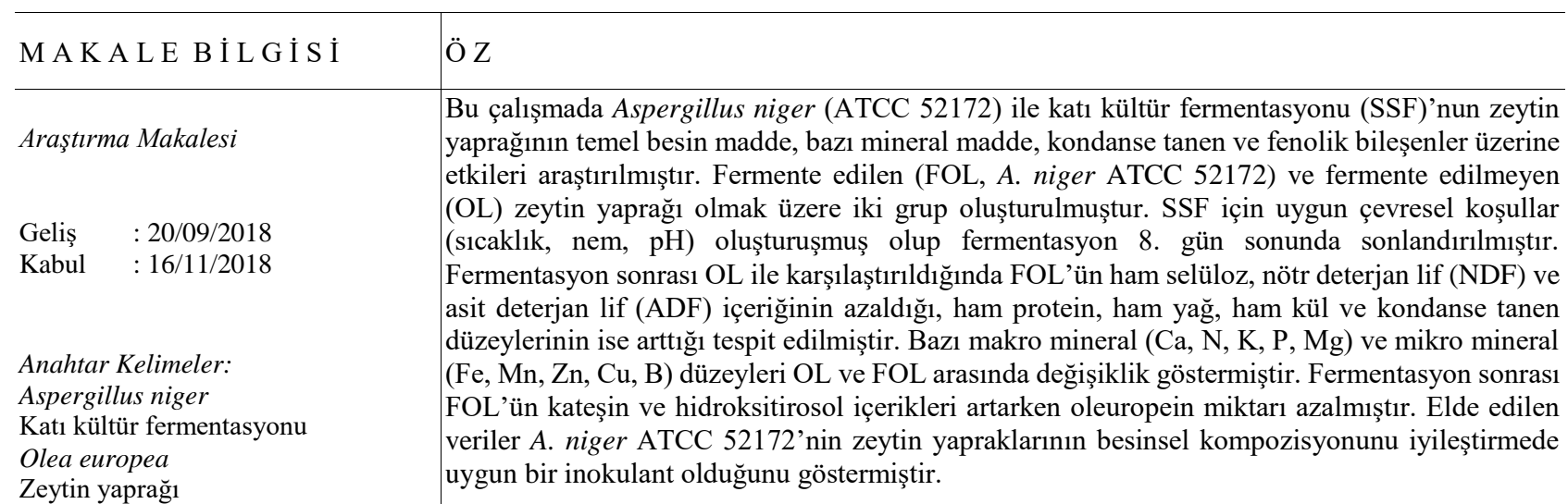

Bitki 


\section{Introduction}

Olive leaf is an agricultural by-product that emerges during pruning $(10 \%$ by weight) and/or harvesting processes, approximately $25 \mathrm{~kg}$ olive leaf from each tree (Molina-Alcaide and Yáñez-Ruiz, 2008). It is thought that olive leaves can be harmful to the environment due to containing lignocellulosic components (Varmaghany et al., 2013).

Olive leaves (OL) have been used in animal feeding traditionally in Mediterranean countries (Yanez Ruiz et al., 2004). Previous studies showed that OL could improve fatty acid profile of sheep and goat milk (Abbeddou et al., 2011a; Tsiplakou and Zervas, 2008), enhance egg yolk color (Cayan and Erener, 2015), improve immunity (Varmaghany et al., 2013) and reduce abdominal fat (Shafey et al., 2013) in broiler. However, it was reported that OL could not affect egg production in quails (Christaki et al., 2011) and milk yield of sheep (Abbeddou et al., $2011 b$ ). It also was affected negatively ruminal fermentation in goat and ram (Yanez Ruiz et al., 2004), reduced feed intake and body weight in pigs (PaivaMartins et al., 2009). It has been suggested that these negative results are due to the low nutritional composition of olive leaf and it's antinutritional components (MartínGarcía et al., 2003). Some methods such as chemical process, drying, fermentation etc. have been used to improve nutritional components of feedstuffs for years (Aro, 2008). In recent years, fermentation has increased popularity in animal nutrition due to the positive changes that have been introduced in the feedstuffs or agricultural by-products. However, there is a little study which was reported that the effects of fermented olive leaves with $A$. niger on main nutritional composition and tannic acid content (Xie et al., 2016). Morever, there is no information about the effect of $A$. niger on phenolic compounds, mineral and condensed tannin content. For this reason, this study was conducted to investigate the effects of $A$. niger on main nutritional composition, phenolic compounds, mineral and condensed tannin of OL.

\section{Material and Method}

\section{Microorganisms and Substrate}

A. niger ATCC 52172 was obtained from the American Type Culture Collection (ATCC). OL (Olea europaea L. cv. Gemlik) were collected from an olive garden in Aydin province of Turkey $\left(37^{\circ} 45^{\prime} 32^{\prime \prime} \mathrm{K}, 27^{\circ} 45^{\prime} 11^{\prime \prime} \mathrm{D}\right)$. Leaves were dried in the shade at approximately $30{ }^{\circ} \mathrm{C}$ on $15-20 \%$ humidity for three days and were stored at room temperature on a bench until fermentation.

\section{Solid-state Fermentation}

Olive leaves were milled to a size of $2 \mathrm{~mm}$ before being sterilized by autoclaving at $121^{\circ} \mathrm{C}$ for $15 \mathrm{~min}$. The nutritional salt (glucose: urea: $(\mathrm{NH} 4)_{2} \mathrm{SO}_{4}$ : peptone: $\left.\mathrm{KH}_{2} \mathrm{PO}_{4}: \mathrm{MgSO} 4.7 \mathrm{H}_{2} \mathrm{O}=4: 2: 6: 1: 4: 1\right)$ were mixed with the substrate to encourage microorganism to grow after sterilizing phase. Each A. niger strain cultured in PotatoDextrose-Agar (PDA) was added to olive leaf substrate at $10^{6}$ spore count, and uninoculated OL were assigned as control. Samples were incubated at $60^{\circ} \mathrm{C}$ for 48 hours. Afterward, samples were dried at room temperature for six days in which samples reached approximately $90 \%$ dry matter. Three replicate were prepared for each treatment.

\section{Main Nutritional Components Analysis}

Ash (method, 942.05, AOAC, 1990), crude protein (CP, method, 976.06, AOAC, 1990), ether extract (EE, method, 920.29, AOAC, 1990), crude fiber (CF, method, 973.18, AOAC, 1990) analyses of OL before and after SSF were conducted. Nitrogen-free extract (NFE) is determined by subtracting water, ash, $\mathrm{CP}, \mathrm{CF}$, and EE found in the feed from 100. Neutral detergent fiber (NDF) and acid detergent fiber (ADF) analyses were conducted according to Van Soest (1991) using the ANKOM ${ }^{200 / 220}$ fiber analyzer (ANKOM corporation ${ }^{\circledR}$ Technology Fairport, NY). Measurement of each sample was conducted three times, and the average was taken.

\section{Condensed Tannin Analysis}

Condensed tannin was determined by Butanol-HCl method (Makkar et al., 1995). Samples (0.01 g) were mixed with $6 \mathrm{ml}$ solution (n-butanol, $\mathrm{HCl}$ and $\mathrm{FeSO} 4$, $95 ; 5 ; 0.05$ ) and boiled in a condenser unit for an hour. Samples were quickly cooled in iced water after boiling and analysed with a spectrometer (Genesys 10S UV-Vis, USA) at $550 \mathrm{~nm}$ wavelength.

\section{Mineral Analysis}

Macro (Ca, N, K, P, Mg) and micro mineral (Fe, Mn, $\mathrm{Zn}, \mathrm{Cu}, \mathrm{B})$ analysis were performed according to the method described by AOAC (1990). Briefly, samples were dried at $65^{\circ} \mathrm{C}$ for 48 hours. Five g samples were taken from dried samples and mixed with $6 \mathrm{ml} 65 \%$ nitric $\mathrm{HClO}_{4}$ and kept at room temperature for 24 hours. Samples were heated in the hot plate on $100-150{ }^{\circ} \mathrm{C}$ until they turn to yellow. Samples were cooled and diluted to $50 \mathrm{ml}$ with distilled water. Diluted samples were analysed by inductively coupled plasma spectrometry on PerkinElmer Elan DRCe ICP-MS (PerkinElmer SCIEX, Shelton, CT).

\section{Determination of Phenolic Compounds}

Olive leaves analysed for phenolic compounds according to Benavente-Garcia et al. (2000) before and after fermentation. Olive leaf extract was dissolved in dimethylsulfoxide in the ratio of $5 \mathrm{mg} / \mathrm{ml}$ and filtered through a $0.45 \mu \mathrm{m}$ nylon membrane. HPLC used in the analyse was Hewlett Packard Series HP 1050 with LiChrospher RP18-5 analytical column (250x4 mm i.d., HICHROM, UK) and Waters 486 absorbance detector (Waters Corporation, USA).

\section{Statistical Analysis}

Since mineral analysis was performed on a single sample per time point, no statistical analysis was possible. The other experiments were carried out triplicate, and results were expressed as means with pooled standard error of means (SEM). Differences between treatments were tested using ANOVA and Duncan's multiple range test (SPSS 21.0 Statistics). 


\section{Results}

Nutritional composition of OL was varied with SSF (Table 1). After fermentation, although CF, NDF, ADF of FOL were decreased $(\mathrm{P}<0.05)$ its $\mathrm{CP}, \mathrm{EE}$, ash $(\mathrm{P}<0.05)$ and condensed tannin content $(\mathrm{P}<0.001)$ were increased as compared to OL (Figure 1).

Olive leaves some macro minerals $(\mathrm{Ca}, \mathrm{N}, \mathrm{K}, \mathrm{F}$ and $\mathrm{Mg}$ ) and micro minerals ( $\mathrm{Fe}, \mathrm{Mn}, \mathrm{Zn}, \mathrm{Cu}$ and $\mathrm{Br}$ ) were increased after fermentation (Table 2). Phenolic compounds of olive leaf were varied between OL and FOL. While oleuropein was decreased, catechin and hydroxytyrosol were increased (Table 3).

Mineral analysis was performed on a single sample each time. Therefore, no statistical analysis was possible.

Phenolic compound analysis was performed on a single sample each time. Therefore, no statistical analysis was possible. ND: not detected.

\section{Discussion}

This study shows that nutritional composition of FOL can be enhanced by SSF. These results have been similar to previous studies which were reported that $\mathrm{CP}, \mathrm{EE}$, and ash content of cassava starch residues (Aro, 2008), cassava root and peels (Aderemi and Nworgu, 2007), cassava pulp (Iyayi and Losel, 2001), cassava bagasse (Vandenberghe et al., 2000), Ginkgo biloba leaves (Cao et al., 2012; Zhang et al., 2013), olive leaf (Xie et al., 2016) and sour cherry kernel (Güngör et al., 2017) could be increased by SSF.

Crude protein level of FOL was increased by SSF in this study. Increase in CP content of OL could be explained with protease produced by A. niger as reported previous studies (Raimbault, 1998; Vandenberghe et al., 2000; Iyayi and Losel, 2001; Aderemi and Nworgu, 2007; Aro, 2008; Dei et al., 2008a; Okpako et al., 2008; Cao et al., 2012; Zhang et al., 2013; Wu et al., 2015; Xie et al., 2016; Güngör et al., 2017). Cellulose is a carbohydrate found in the cell walls of plants and is generally at a high level in agricultural wastes (Graminha et al., 2008). High content of cellulose lowers feed's digestibility (JøRgensen et al., 1996). In this study, CF, NDF and ADF contents of FOL were decreased by fermentation. Xie et al. (2016) reported that $A$. niger can produce cellulase in olive leaf. It is thought that decrease in $\mathrm{CF}$ in this study may be due to this cellulase production. This idea were supported by previous studies (on cassava starch residues, cassava pulp and peels, and shea nut (Aderemi and Nworgu, 2007; Aro, 2008; Dei et al., 2008a). On the other hands, Okpako et al. (2008) suggested that $A$. niger increased CF in SSF as reported by Güngör et al., (2017). Discrepancy among the studies can be explained with used different inoculant (A. niger, $A$. flavus, $A$. nidulans etc.), fermentation conditions (temperature, $\mathrm{pH}$, humidity etc.) or substrate (cassava, sour cherry kernel, olive leaf etc). In the study, ash content of FOL was increased after fermentation. This can be attributed to increase in mineral content. As a matter of fact, mineral content of the olive leaf was increased after fermentation (Table 2). Solid-state fermentation can not be affected NFE content of the OL. This result is consistent with previous studies which were reported that SSF cannot varied NFE content (Vandenberghe et al., 2000; Aro, 2008; Okpako et al., 2008; Güngör et al., 2017).
Table 1 Effect of $A$. niger on main nutritional components and condensed tannin content of olive leaves in solid-state fermentation

\begin{tabular}{l|rrrc}
\hline Composition (\%) & \multicolumn{1}{|c}{ OL } & \multicolumn{1}{c}{ FOL } & SEM & P \\
\hline CP & 12.20 & 14.14 & 0.439 & $* * *$ \\
EE & 2.34 & 3.15 & 0.185 & $* * *$ \\
Ash & 6.27 & 6.74 & 0.111 & $*$ \\
NFE & 53.58 & 53.13 & 0.182 & NS \\
CF & 25.61 & 22.84 & 0.631 & $* * *$ \\
NDF & 39.48 & 45.47 & 1.348 & $* * *$ \\
ADF & 26.96 & 33.39 & 1.441 & $* * *$ \\
\hline
\end{tabular}

NS: Not Significant $(\mathrm{P}>0.05),{ }^{*}: \mathrm{P}<0.05, * *: \mathrm{P}<0.01, * * *: \mathrm{P}<0.001$

Table 2 Effects of $A$. niger on macro and micro mineral contents of olive leaves in solid-state fermentation

\begin{tabular}{|c|c|c|}
\hline Minerals & $\mathrm{OL}$ & FOL \\
\hline \multicolumn{3}{|c|}{ Macro (\%) } \\
\hline Calcium & 12.12 & 14.41 \\
\hline Nitrogen & 1.95 & 2.26 \\
\hline Potassium & 1.06 & 1.26 \\
\hline Phosphorus & 0.36 & 0.44 \\
\hline Magnesium & 0.22 & 0.25 \\
\hline \multicolumn{3}{|c|}{ Micro (ppm) } \\
\hline Iron & 65.28 & 99.00 \\
\hline Manganese & 37.44 & 42.20 \\
\hline Zinc & 17.18 & 21.50 \\
\hline Copper & 2.40 & 3.40 \\
\hline Boron & 1.98 & 2.01 \\
\hline Total $(\%)$ & 15.72 & 18.64 \\
\hline
\end{tabular}

Table 3 Effects of $A$. niger on phenolic compounds of olive leaves in solid-state fermentation

\begin{tabular}{l|rc}
\hline \multicolumn{1}{c|}{$\begin{array}{c}\text { Phenolic compounds } \\
\text { (1 g CE/1 g leaf })\end{array}$} & OL & FOL \\
\hline Oleuropein & 23.24 & 2.49 \\
Rutin & ND & ND \\
Catechin & 0.51 & 2.50 \\
Epicatechin & ND & ND \\
Hydroxytyrosol & 0.42 & 2.48 \\
Kaempferol & ND & ND \\
Quercetin & ND & ND \\
Gallic acid & ND & ND \\
Tannic acid & ND & ND \\
Caffeic acid & ND & ND \\
Vanillic acid & ND & ND \\
Vanillin & ND & ND \\
\hline
\end{tabular}

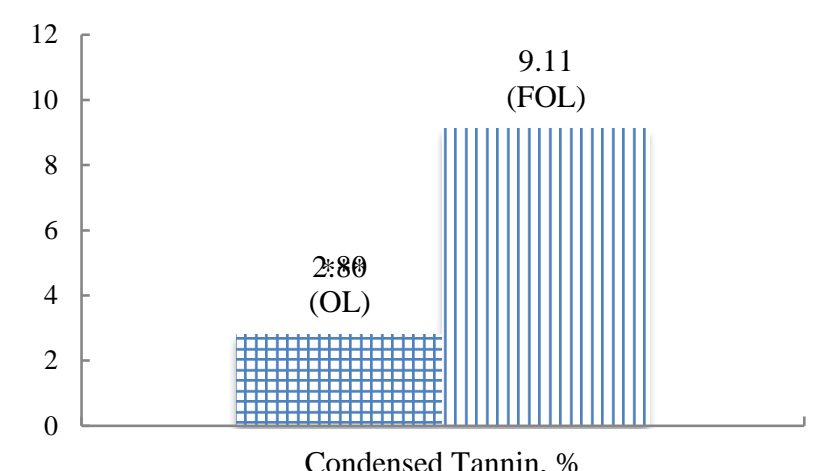

Figure 1 Effects of Aspergillus niger on condensed tannin content of olive leaves in solid-state fermentation (***: P<0.001; OL: unfermented olive leaf; FOL: fermented olive leaf) 
Fungi have ability to produce microbial lipids in the substrate during fermentation (Hui et al., 2010). As a matter of fact, olive leaf's EE content was increased by fermentation in this study. Similar results obtained from the studies on cassava starch residues (Aro, 2008) and shea nut (Dei et al., 2008a). However, in some studies, ether extract content either remained the same (Aro, 2008; Güngör et al., 2017; Okpako et al., 2008) or decreased (Güngör et al., 2017) by fermentation.

Tannins are water-soluble polyphenols found in plants (Scalbert, 1991). It is divided into hydrolyzable and nonhydrolyzed (condensed) tannin (Akiyama et al., 2001). Olive leaf's condensed tannin was increased in this study. Xie et al. (2016) reported that olive leaf's tannic acid which is a type of hydrolyzable tannin was decreased by fermentation. Dei et al. (2008a) and Dei et al. (2008b) also reported a decrease in hydrolyzable tannin of shea nut. Condensed tannin in olive leaf was reported to be free $(3.53 \%)$, bound to proteins $(1.25 \%)$ and largely bound to cellulose (6.35\%; Yanez Ruiz et al., 2004). Increase in condensed tannin content may be attributed to the fact that the cellulose and protein were broken down by fermentation and as a result, the bound tannins were free. Akiyama et al. (2001) reported that condensed tannins were more difficult to break down than hydrolyzable tannins. This may be attribute that condensed tannin in OL could not broke down by A. niger.

Major phenolic compounds in OL are oleuropein, hydroxytyrosol, luteolin, apigenin and verbascoside (Benavente-Garcia et al., 2000). In this study, phenolic compounds were varied between OL and FOL. While catechin and hydroxytyrosol of FOL were increased, oleuropein of OL was decreased after fermentation. This can be explained fermentation process because it can alter the amount and proportion of secondary metabolites derived from medicinal plants, resulting from smaller particles created by microbial digestion, and enhance the original treatment efficacy of active ingredients (Dei et al., 2008a) by the action of enzymes produced by bacteria, yeast and molds.

\section{Acknowledgement}

Author thank to The Scientific and Technological Research Council of Turkey (TUBITAK, TOVAG114R110) because of providing A. niger inoculant (ATCC 52172).

\section{Conclusion}

In conclusion, SSF increased $\mathrm{CP}, \mathrm{EE}$, ash, minerals, and condensed tannin, and decreased $\mathrm{CF}$, NDF, ADF contents of OL. Phenolic components were varied by increasing of catechin and hydroxytyrosol and decreasing of oleuropein. These results showed that A. niger ATCC 52172 strain could be suitable inoculant to improve the nutritional content of OL in SSF.

\section{References}

Abbeddou S, Rischkowsky B, Hilali ME-D, Hess HD, Kreuzer M. 2011a. Influence of feeding Mediterranean food industry by-products and forages to Awassi sheep on physicochemical properties of milk, yoghurt and cheese. J Dairy Res, 78:42635. DOI: $10.1017 /$ S0022029911000665.
Abbeddou S, Rischkowsky B, Richter EK, Hess H, Kreuzer M. 2011b. Modification of milk fatty acid composition by feeding forages and agro-industrial byproducts from dry areas to Awassi sheep. J Dairy Sci, 94:4657-68. DOI: 10.3168/jds.2011-4154.

Aderemi F, Nworgu F. 2007. Nutritional status of cassava peels and root sieviate biodegraded with Aspergillus niger. Am Eurasian J Agric Environ Sci, 2:308-11.

Akiyama H, Fujii K, Yamasaki O, Oono T, Iwatsuki K. 2001. Antibacterial action of several tannins against Staphylococcus aureus. J Antimicrob Chemother, 48:487-91. DOI: 10.1093/jac/48.4.487.

AOAC. 1990. Official methods of analysis. J Assoc Off Anal Chem, 1:684.

Aro S. 2008. Improvement in the nutritive quality of cassava and its by-products through microbial fermentation. African Journal of Biotechnology, 7: 4789-97.

Benavente-Garcia O, Castillo J, Lorente J, Ortuno A, Del Rio J. 2000. Antioxidant activity of phenolics extracted from Olea europaea L. leaves. Food Chem, 68:457-62. DOI: 10.1016/S0308-8146(99) 00221-6.

Cao F, Zhang X, Yu W, Zhao L, Wang T. 2012. Effect of feeding fermented Ginkgo biloba leaves on growth performance, meat quality, and lipid metabolism in broilers. Poult Sci, 91:1210-21. DOI: 10.3382/ps.2011-01886.

Cayan H, Erener G. 2015. Effect of olive leaf (Olea europaea) powder on laying hens performance, egg quality and egg yolk cholesterol levels. Asian-Australas J Anim Sci, 28:538. DOI: 10.5713/ajas.14.0369.

Christaki E, Bonos E, Florou-Paneri P. 2011. Comparative evaluation of dietary oregano, anise and olive leaves in laying Japanese quails. Revista Brasileira de Ciência Avícola, 13:97-101. DOI: 10.1590/S1516-635X2011000200003.

Dei H, Rose S, Mackenzie A, Amarowicz R. 2008a. Growth performance of broiler chickens fed diets containing shea nut (Vitellaria paradoxa, Gaertn.) meal fermented with Aspergillus niger. Poult Sci, 87:1773-8. DOI: 10.3382/ps.2008-00055.

Dei HK, Rose S, Mackenzie A. 2008b. Effects of fungal (Aspergillus niger or Ceriporiopsis subvermispora) fermentation on the nutritive value of shea nut (Vitellaria paradoxa) meal for broiler chicks. Br Poult Sci, 49:360-7. DOI: $10.1080 / 00071660802126651$.

Graminha E, Gonçalves A, Pirota R, Balsalobre M, Da Silva R, Gomes E. 2008. Enzyme production by solid-state fermentation: Application to animal nutrition. Anim Feed Sci Technol, 144:1-22. DOI: 10.1016/j.anifeedsci.2007.09.029.

Güngör E, Altop A, Öztürk E, Erener G. 2017. Nutritional changes of sour cherry (Prunus cerasus) kernel subjected to Aspergillus niger solid-state fermentation. Journal of Tekirdag Agricultural Faculty:99-103.

Hui L, Wan C, Hai-Tao D, Xue-Jiao C, Qi-Fa Z, Yu-Hua Z. 2010. Direct microbial conversion of wheat straw into lipid by a cellulolytic fungus of Aspergillus oryzae A-4 in solid-state fermentation. Bioresour Technol, 101:7556-62. DOI: 10.1016/j.biortech.2010.04.027.

Iyayi EA, Losel DM. 2001. Protein enrichment of cassava byproducts through solid state fermentation by fungi. The Journal of Food Technology in Africa, 6:116-8. DOI: 10.4314/jfta.v6i4.19301.

JøRgensen H, Zhao X-Q, Knudsen KEB, Eggum BO. 1996. The influence of dietary fibre source and level on the development of the gastrointestinal tract, digestibility and energy metabolism in broiler chickens. Br J Nutr, 75:379-95. DOI: 10.1079/BJN19960141.

Makkar H, Blümmel M, Becker K. 1995. Formation of complexes between polyvinyl pyrrolidones or polyethylene glycols and tannins, and their implication in gas production and true digestibility in in vitro techniques. Br J Nutr, 73:897-913. DOI: 10.1079/BJN19950095. 
Martín-García A, Moumen A, Ruiz DY, Alcaide EM. 2003. Chemical composition and nutrients availability for goats and sheep of two-stage olive cake and olive leaves. Anim Feed Sci Technol, 107: 61-74. DOI: 10.1016/S0377-8401 (03)00066-X

Molina-Alcaide E, Yáñez-Ruiz D. 2008. Potential use of olive byproducts in ruminant feeding: A review. Anim Feed Sci Technol, 147: 247-64. DOI: 10.1016/j.anifeedsci. 2007 .09 .021 .

Okpako C, Ntui V, Osuagwu A, Obasi F. 2008. Proximate composition and cyanide content of cassava peels fermented with Aspergillus niger and Lactobacillus rhamnosus. J Food Agric Environ, 6:251-5.

Paiva-Martins F, Barbosa S, Pinheiro V, Mourão JL, OutorMonteiro D. 2009. The effect of olive leaves supplementation on the feed digestibility, growth performances of pigs and quality of pork meat. Meat Sci, 82:438-43. DOI: 10.1016/j.meatsci.2009.02.014.

Raimbault M. 1998. General and microbiological aspects of solid substrate fermentation. Electron J Biotechnol, 1:26-7. DOI: 10.2225/vol1-issue3-fulltext-9.

Scalbert A. 1991. Antimicrobial properties of tannins. Phytochemistry, 30:3875-83. DOI: 10.1016/00319422(91)83426-L.

Shafey TM, Al-Ruqaei IM, Almufarij SI. 2013. Effect of feeding olive leaves extract (oleuropein) on the performance, nutrient utilization, small intestine and carcass characteristics of broiler chickens. J Anim Vet Adv, 12:740-6. DOI: 10.3923/javaa.2013.740.746.

Tsiplakou E, Zervas G. 2008. The effect of dietary inclusion of olive tree leaves and grape marc on the content of conjugated linoleic acid and vaccenic acid in the milk of dairy sheep and goats. J Dairy Res, 75:270-8. DOI: 10.1017/ S0022029908003270.
Vandenberghe LP, Soccol CR, Pandey A, Lebeault J-M. 2000. Solid-state fermentation for the synthesis of citric acid by Aspergillus niger. Bioresour Technol, 74:175-8. DOI: 10.1016/S0960-8524(99)00107-8.

Varmaghany S, Rahimi S, Torshizi MK, Lotfollahian H, Hassanzadeh M. 2013. Effect of olive leaves on ascites incidence, hematological parameters and growth performance in broilers reared under standard and cold temperature conditions. Anim Feed Sci Technol, 185:60-9. DOI: 10.1016/j.anifeedsci.2013.07.002.

Wu Q, Wang Z, Wang G, Li Y, Qi Y. 2015. Effects of feed supplemented with fermented pine needles (Pinus ponderosa) on growth performance and antioxidant status in broilers. Poult Sci, 94:1138-44. DOI: 10.3382/ps/pev013.

Xie P, Huang L, Zhang C, Zhang Y-1. 2016. Nutrient assessment of olive leaf residues processed by solid-state fermentation as an innovative feedstuff additive. J Appl Microbiol, 121:2840. DOI: $10.1111 /$ jam.13131.

Yanez Ruiz D, Moumen A, Martin Garcia A, Molina Alcaide E. 2004. Ruminal fermentation and degradation patterns, protozoa population, and urinary purine derivatives excretion in goats and wethers fed diets based on two-stage olive cake: Effect of PEG supply. J Anim Sci, 82:2023-32. DOI: $10.2527 / 2004.8272023 x$.

Zhang X, Zhao L, Cao F, Ahmad H, Wang G, Wang T. 2013. Effects of feeding fermented Ginkgo biloba leaves on small intestinal morphology, absorption, and immunomodulation of early lipopolysaccharide-challenged chicks. Poult Sci, 92:119-30. DOI: 10.3382/ps.2012-02645. 